\title{
Flying the Rainbow Flag at the United Nations
}

\author{
Douglas Sanders \\ Mahidol University, Thailand \\ Email: sanders_gwb@yahoo.ca
}

\begin{abstract}
Issues of sexual orientation and gender identity were raised in two of the United Nations intergovernmental world conferences on women, 1985 and 1995, and in the Vienna world conference on human rights in 1993. From 2006 a number of LGBTI Non-Governmental Organizations gained ongoing 'consultative status' from the Economic and Social Council allowing access to regular UN human rights events. Leading human rights NGOs, such as Amnesty International and Human Rights Watch began to address LGBTI issues. The Human Rights Council condemned violence and discrimination on grounds of sexual orientation and gender identity in 2011 and later authorized an independent expert, whose mandate was renewed for a second term. The UNDP "Being LGBT in Asia" program has been active in eight Asian states, including five in ASEAN: Cambodia, Indonesia, Philippines, Thailand and Vietnam. Strong support came from Ban Ki-moon as UN Secretary General, as well as from the Office of the UN High Commissioner for Human Rights and other agencies.
\end{abstract}

Keywords: United Nations, Sexual Orientation, Gender Identity, LGBTI, Human Rights Council, Non-Governmental Organizations

\section{INTRODUCTION}

The 1948 Universal Declaration of Human Rights declares that all people are "born free and equal in dignity and rights." Article 2 lists race and sex as two of nine examples of forbidden grounds for discrimination. It then adds "or other status." There is no express mention of sexual orientation or gender identity, but the provision is 'open ended', allowing its application to other groupings, for example, to persons with disabilities or migrant workers. The same use of "other status" occurs in the two landmark $U \boldsymbol{N}$ human rights treaties of $1966 .{ }^{1}$

The regional intergovernmental human rights treaties and institutions that have developed in Europe, Latin America, Africa, and Southeast Asia in the post-war period have similar wording. LGBTI (lesbian, gay, bisexual, transgender, and

1 Article 2 (2) of the International Covenant on Economic, Social and Cultural Rights, Article 2(1) of the International Covenant on Civil and Political Rights. Domestic laws against discrimination often have closed lists. 
intersex) are neither expressly included nor excluded. While Malaysia, supported by Brunei and Singapore, spoke against the inclusion of LGBTI in the drafting of the 2012 ASEAN Declaration of Human Rights, the declaration has the same open-ended wording as the $U D H R^{2}$

\section{THE ROLE OF WOMEN'S RIGHTS IN CREATING SPACE FOR LESBIANS AT THE UNITED NATIONS}

Internationally focused women's advocacy organizations predate the League of Nations and secured a clause in the Covenant of the League that stated that all positions in the organization were to be open to both men and women. ${ }^{3}$ The Charter of the United Nations specifically condemns discrimination on grounds of race and sex.

The UN declared 1975 as International Women's Year. The highlight was a major women's conference in Mexico City and the announcement of an official $U N$ Decade for Women." The Convention on the Elimination of All Forms of Discrimination against Women was adopted by the General Assembly in 1979 and called for social and cultural change. It has been widely signed, but with a high level of reservations. The four international women's conferences between 1975 and 1995 (Mexico City, Copenhagen, Nairobi, Beijing), and the other work on women's issues in the UN, provided a context within which lesbian issues could possibly be raised. In sharp contrast, attention to gay men focused on (a) specific criminal law prohibitions of male-male sexual acts which continued in 'common law' jurisdictions (United Kingdom and former colonies) and (b) the Aids pandemic that arose in the 1980s.

Excelsior, the largest circulation newspaper in Mexico, denounced those demanding that lesbianism be included on the agenda of the 1975 Mexico City conference, calling lesbianism a pathology and a sexual aberration.

"Claudia Hinojosa, one of the early lesbian feminist activists in Mexico City, has observed that the emergence of lesbianism at the 1975 conference took everyone by surprise. Yet, she says, it became the frame for the first significant exchange between Mexican lesbians and organized lesbian feminists from other countries. Further while

2 The Thai representative on the ASEAN Intergovernmental Commission on Human Rights urged the inclusion of 'sexual orientation' in the list of examples of prohibited discrimination in the document. That was rejected, but the word "gender" was substituted for the word "sex", as compromise. See Human Rights After Seventy Years: The View from the South, by Yuyun Wahyuningrum (Heinrich Boll Stiftung, 2018); Joke Swiebel, "Lesbian, gay, bisexual and transgender human rights: the search for an international strategy" (2009) 25:1 Contemporary Politics $19-35$ at 25-27.

3 The Women's International League for Peace and Freedom was founded in 1915 and internationally active.

4 See Jocelyn Olcott, International Women's Year: The Greatest Consciousness-Raising Event in History (Oxford University Press, 2017). 
the UN Conference and the NGO (non-governmental organization) parallel event made no official pronouncements on the issue, the scandal that the press made over lesbianism gave it high visibility both in Mexico and among delegates at the conference. Within the NGO Tribune, impromptu lesbian workshops were scheduled which received a large response and also became the only space for discussion by women of their own sexuality of any kind." ${ }^{5}$

At the 1980 Copenhagen conference "lesbian groups primarily from Western countries proposed six workshops for the parallel NGO Forum, which were regularly scheduled and well-attended. ...lesbians moved from outrageous scandal in Mexico to low-key networking and dialogue in Copenhagen." ${ }^{\prime \prime}$

Until the 1985 Nairobi conference, lesbian activism within the UN programs was confined to the non-governmental parallel conference, with no acknowledgement in the official government conference. The first known statement in a United Nations governmental forum supporting LGBT rights came from the junior minister in the government of the Netherlands who headed the Dutch delegation at the 3rd $U \boldsymbol{N}$ World Conference on Women, held in Nairobi in 1985. Annelien Kappeyne van de Coppello said:

"Among the many different groups of women who are attending this Conference, lesbian women are in a special position. ... We can regard the fact that lesbian women are beginning to be visible and are articulating their claims to equal treatment, as a hopeful sign in the struggle for equal rights and opportunities in which lesbian women share.

...heterosexual behavior should have no more right to existence than homosexual behavior."”

In advance of the Nairobi conference, lesbians in the Netherlands had formulated a statement of their demands and pressed the government to support them at the conference. ${ }^{8}$ The government had a very recent policy statement on gender equality, but that statement made no reference to lesbians or sexual orientation. There was a key activist within the government. Joke Swiebel was part of the gender equality division within the Ministry of Social Affairs and Employment and in charge of the preparations for the Nairobi conference. She wrote the speech. She inserted the references to lesbians and homosexuality. While she had no specific instructions to include the references, the text gained approval from the Foreign Office and the Minister before it was delivered. ${ }^{9}$ No

5 Charlotte Bunch, Foreword, Rachel Rosenbloom, Unspoken rules: sexual orientation and women's human rights, International Gay and Lesbian Human Rights Commission, ed (London: Cassell, 1995) at iv.

6 Ibid.

7 Swiebel, "Lesbian, gay, bisexual and transgender human rights”, supra note 2.

8 Sylvia Borren, Lesbians in Nairobi (Second ILGA Pink Book, 1988) at 59.

9 Personal communication, March 31, 2021. And see Swiebel, "Lesbian, gay, bisexual and transgender human rights”, supra note 2. 
debate or resolution with reference to lesbians or homosexuality followed in the intergovernmental forum at Nairobi. Joke Swiebel went on to a long career of lesbian and gender activism within the Netherlands and as an elected member of the European Parliament.

There was an official Non-Governmental Organization (NGO) Forum, parallel to the Nairobi intergovernmental conference, a standard UN practice, as we have seen. The Kenyan Minister of Culture and Social Affairs had stated at the UN Commission on the Status of Women that he did not want lesbian issues raised at the Forum. ${ }^{10}$ ILIS, the International Lesbian Information Service applied to the UN organizers to hold specific lesbian-focused workshops in the NGO Forum, and a number were held. ${ }^{11}$

Lesbian activists handed out 4,000 copies of a pamphlet explaining their goals.

"On the second day of registration a table was borrowed, and a 'lesbian stand' set up. ... Within half an hour Dame Nita Barrow, top convenor (organizer) of the conference was there ordering the lesbians to pack up their materials, warning that they might get in trouble with "the authorities." The argument which ensued was reported widely in the press - and meant that ILIS women immediately got the high-profile that they wanted. The table was removed, but for the remainder of the conference lesbians sat at the same spot on the lawn, handing out material and supplying information." ${ }^{12}$

The visibility of lesbian-identified women had been achieved, perhaps more clearly than before in any UN context.

"The highlight was a Lesbian Press Conference held at the Forum where women from all regions spoke. A Third World lesbian statement sought to counter the idea that this was a white western issue declaring "If it seems that lesbianism is confined to white western women, it is often because Third World Lesbians and lesbians of color come up against more obstacles to our visibility ...

10 Kenyan criminal law prohibited male-male homosexual acts but was silent on lesbian acts.

11 In 1980, at the time of the 2nd UN World Conference on Women, held in Copenhagen, ILIS was just starting. There were no lesbian workshops in the NGO Forum in Copenhagen, but some contacts were made that supported the organization. ILIS began within ILGA, which was very European in membership and focus. ILIS left ILGA and focused on outreach to developing countries. Sylvia Borren writes of assistance to organizations in Latin America. Asian activists within ILIS formed a separate Asian Lesbian Network, which held four regional conferences (Thailand, Japan, Taiwan, Philippines). ILIS and ALN ended in the late 1990s. OutRight Action International (then the International Lesbian and Gay Human Rights Commission) began in 1990 and was first engaged with the UN at the 1995 4th UN World Conference on Women in Beijing.

12 Borren, supra note 8 at 64 . 
But this silence has to be seen as one more aspect of women's sexual repression and not as a conclusion ...."

\section{ACCREDITING A BROAD-BASED GAY, LESBIAN PRESENCE IN THE UN SYSTEM}

In 1991, a committee of the UN Economic and Social Council met to consider the first application for "consultative status" for ILGA (the International Lesbian and Gay Association). Lesbian activist Lisa Power represented the organization.

"I spoke about lesbian and gay rights, and what ILGA was, and why we should be accepted alongside other human rights organizations, and I also answered a number of (very insulting) questions and remarks in as calm a way as I could. ... remarks like the representative from a North African country who started by calling me "an abomination on the face of the earth."

The majority of countries on the committee supported accreditation, but there were strong religiously based objections from Libya and Oman. As well, the Philippine representative expressed discomfort with accreditation. The committee had always required consensus, so accreditation was not approved. A decision was put off for two years.

On August $6^{\text {th }}$, 1992, the present writer, made a statement in the annual Geneva session of the $U N$ Sub-Commission on the Prevention of Discrimination and Protection of Minorities. I had been authorized to try to make a statement at the UN by the International Lesbian and Gay Association conference in Paris in July. I identified myself as a gay man, cited discrimination by my country, Canada, and called for the UN human rights system to take up our issues. This seemed a pioneering statement by an 'out' LGBTI person in a fairly central UN human rights forum. ${ }^{15}$

What was the response? Observers wrote that there was "open hostility" on the part of some of the members of the Sub-Commission. "When the session broke for lunch, the NGO that had authorized my intervention, Human Rights Advocates, was immediately grilled by two outraged Commission members about my relationship to the organization, and whether I was speaking on its' behalf. My

13 Bunch, supra note 5 at v.

14 Lisa Power, personal communication, March 8, 2021.

15 The Sub-Commission was designed to be an 'expert' support body for the Commission on Human Rights, the key 'political' body in the UN system on human rights. The Commission reported to the Economic and Social Council and through that body to the General Assembly. The reform that created the Human Rights Council to replace the Commission ended the existence of the Sub-Commission. One great success of the Sub-Commission was its pioneering work on the rights of indigenous people.

16 Alya Z Kayal, Penny L Parker \& David Weissbrodt, "The Forty-Fourth Session of the UN Sub-Commission on Prevention of Discrimination and Protection of Minorities" (1993) 15:2 Human Rights Quarterly $410-458$ at 457. 
sponsor was harassed, and no Sub-Commission member showed any interest in engaging with me on LGBTI issues.

\section{UN WORLD CONFERENCE ON HUMAN RIGHTS}

The following year, at the $U N$ World Conference on Human Rights in Vienna, $I L G A$ was accredited along with two other LGBTI organizations for the parallel NGO Forum. As at the Nairobi conference, this was temporary, for the one event. Regular accreditation rules had been waived to ensure that groups from outside the West could be present. Around six western LGBTI activists were accidental beneficiaries of this waiver.

We were there - officially - with proper identification badges bearing the names of our organizations. Kurt Krickler from Vienna. Rodney Croome and Carole Ruthchild from Australia. John Fisher and Douglas Sanders from Canada. We spoke in the one session of the intergovernmental conference that was given over to statements by non-governmental organizations. We could see the members of the various government delegations ignoring this fairly long set of presentations walking around, having coffee, chatting with other delegates. John Fisher, in his prepared statement, said “don't turn your backs on us" - but ironically that was exactly what was happening as we spoke from the observers' gallery behind and above the rows of desks facing the conference podium.

Five Western governments expressly supported sexual orientation equality, in their official conference statements in plenary sessions. They were Australia, Austria, Canada, Germany, and the Netherlands. Five!! Fabulous!! For us this was a breakthrough - even if the statements had merely added the two words 'sexual orientation' to the list of categories for which discrimination was condemned. Canada, for example, in a short sentence, opposed discrimination 'on grounds of sexual orientation or HIV status' seeming to link the categories. In retrospect, the statement seems as much stigmatizing as recognizing, but a clear breakthrough at the time.

Know-it-all Singapore scoffed that most human rights were "still essentially contested concepts." The statement went on to condemn specific nasty trends:

"Singaporeans, and people in many other parts of the world do not agree, for instance, that pornography is an acceptable manifestation of free expression or that homosexual relationships is [sic] just a matter of lifestyle choice. Most of us will also maintain that the right to marry is confined to those of the opposite sex."

17 Copy in possession of the author. While this was in the official Singapore statement to the conference, the country did not attempt to challenge the final conference 'consensus' statement'. Singapore was opposing same-sex marriage before it was legal in any country in the world (though the registration system in Denmark, enacted in 1989, was often referred to as marriage). Denmark had also famously decriminalized pornography, and court decisions in the US were upholding pornography as free expression. Hustler magazine was the leading example of this new freedom in the United States. It was established in 1974 and had a 
They saw what the future could bring, and they didn't like it very much.

Canada was a member of the drafting committee at Vienna. The Canadian government representatives were pressed by Canadians linked to ILGA, and by 'out' Canadian parliamentarian Svend Robinson" to propose adding "sexual orientation" to the non-discrimination list in the draft final declaration of the conference. Swiftly the chairperson skillfully substituted wording that condemned discrimination in general, with no list. We were not included - but we were not excluded either. Still in the closet. Not to be mentioned.

\section{IN AND OUT AT THE UN}

In March 1993, the committee of the Economic and Social Council that considered the accreditation of NGOs met, chaired by Sweden. ILGA was up for consideration again. The consensus decision making tradition was abandoned, for the first time, to approve Human Rights Watch. Most members of the committee then supported the accreditation of $I L G A .^{19}$ The list of approved candidate NGOs moved to the full Economic and Social Council in July. 1993. A roll-call vote was demanded on ILGA, and some states, notably Malaysia, expressed their opposition. They were outvoted. Yves de Matteis of Geneva and the present writer organized subsequent statements in the name of $I L G A$, now accredited, in both the Commission and the Sub-Commission.

1994 saw the breakthrough decision of the UN Human Rights Committee in Toonen v Australia. Criminal laws against adult consensual homosexual acts were held to be in violation of the International Covenant on Civil and Political Rights. Such laws still existed in half the world. The UN committee was following the lead of the European Court of Human Rights decision in Dudgeon $v$ United Kingdom in 1981. In Southeast Asia, Aceh, Brunei, Malaysia, Myanmar, and Singapore have such laws (as do many former British colonies in Africa, the Caribbean, and the Pacific).

The Human Rights Committee in the Toonen case said that discrimination on grounds of sexual orientation was a form of discrimination on grounds of "sex". In 2020 the US Supreme Court made the same ruling in major employment discrimination cases involving two gay men and a transgender woman. ${ }^{20}$ The result of these rulings was to broaden the impact of many constitutional and legislative non-discrimination provisions. The first reference to sexual orientation in the UN

circulation of two million in 1976. See Robert D McFadden, "Larry Flynt, Who Built a Porn Empire With Hustler, Dies at 78", The New York Times (11 February 2021). Much more mainstream was Playboy Magazine with its nude centerfold in each issue.

18 Robinson was a member of the Canadian government delegation, though from an opposition party.

19 France, Greece, Ireland, Russia, Sweden, Bulgaria, Chile, Costa Rica, and Cuba voted in favor. Iraq, Lesotho, Oman, and Sudan voted against accreditation.

20 Bostock v Clayton County, USSC, June 15, 2020. 
'special procedures' came in a 1997 report by the Special Rapporteur on Violence against Women. ${ }^{21}$

ILGA was abruptly suspended in 1994, thanks to the efforts of US Senator Jesse Helms. Two or three controversial $I L G A$ member organizations (out of a few hundred), supported consensual underage gay sex. ${ }^{22}$ The Helms resolution in the US Senate threatened to cut some US UN funding if ILGA was not kicked out. Officially it was suspended. Helms was a known homophobe. ILGA, at its next conference, affirmed support for the UN Convention on the Rights of the Child and expelled those members that did not respect appropriate legal age limits. Hostile voices at the UN then demanded that ILGA supply detailed information on all $I L G A$ member organizations before they would consider lifting the suspension. Since a number of $I L G A$ members at the time functioned clandestinely in hostile countries, the demand could not be met. ${ }^{23}$

In 2001, the UN General Assembly held a Special Session on HIV/AIDS. Karyn Kaplan, the HIV program officer at IGLHRC was invited to speak on a panel. ${ }^{24}$ That invitation was challenged by nine Muslim majority states. Argentina, Canada and Norway filed a motion to have her included "triggering the first debate about a lesbian or gay issue in the UNGA." Sixty-two states supported the motion, against thirty opponents. Kaplan was able to speak. ${ }^{25}$

\section{SOME BITS OF PROGRESS}

The first supportive decision on LGBTI rights in a political body of the UN came in 2002. The resolution renewing the mandate of the mandate of the Special Rapporteur on Extrajudicial, Summary and Arbitrary Executions referred expressly to sexual minorities, among others, as a grouping of concern. Opponents moved to delete the reference. After an acrimonious debate, the motion to delete failed. In subsequent renewals of the mandate, the reference to sexual minorities continued. A 2010 fight to remove the words was actively defeated with strong lobbying by the US (under the Obama presidency). ${ }^{26}$

In 2006 three LGBTI organizations were able to gain UN accreditation, with the support of home governments, including ILGA Europe, the Danish

21 Albert Trithart, "A UN for All? UN Policy and Programming on Sexual Orientation, Gender Identity and Expression, and Sex Characteristics” (2021) International Peace Institute at Annex: Legal and Political Progress on Sogiesc at the UN Table 2. The 2004 report of the Special Rapporteur on Health dealt quite comprehensively with LGBTI issues and faced criticisms from some states.

22 The controversy focused on NAMBLA, the North American Man Boy Love Association, which used its membership in ILGA in publications and pride parades to claim legitimacy.

23 Ryan R Thoreson, Transnational LGBT Activism: Working for Sexual Rights Worldwide (University of Minnesota Press, 2014) at 183.

24 IGLHRC, the International Gay and Lesbian Human Rights Commission, a US NGO without 'consultative' status, had been established in 1990.

25 Thoreson, supra note 23 at 40.

26 Ibid at 185. 
organization $L B L$ and the German organization $L S V D .^{27}$ Others gained the necessary recognition in following years. National organizations, backed by friendly governments, including Brazil, got accreditation. LGBTI organizations were becoming participants in the UN human rights system as regularly accredited NonGovernmental Organizations (NGOs). This put them in the room for UN human rights events, able to talk with government delegations and with limited rights to speak in the sessions. The International Gay and Lesbian Human Rights Commission, a US based NGO, active in relation to the global South, particularly Africa and Latin America, applied for accreditation in May 2007. It faced three years of questions and obstructions, before gaining accreditation. ${ }^{28}$ Eventually, in 2011, $\boldsymbol{L} \boldsymbol{G A}$ finally regained a place as well.

The first well established general human rights NGO to support LGBTI rights was Amnesty International. First, in 1991, it said that individuals imprisoned for consensual adult homosexual acts were "prisoners of conscience", expanding on their founding concern. The full breakthrough on LGBTI rights came in an $\boldsymbol{A I}$ report in $1994 .^{29}$ In August 2001, $A I$ broadened its mandate to condemn all forms of discrimination. And Human Rights Watch came on board with an LGBT program in 2004, and, over time, a much stronger allocation of resources on LGBTI issues. It brought together a fine team of analysts, under first director Scott Long $^{30}$, and second director Graeme Reid. It included Boris Dittrich; the legislator most responsible for opening marriage in the Netherlands. ${ }^{31}$

\section{THE BEJING CONFERENCE}

The LGBTI success at being physically present at the Vienna World Conference was nothing compared to the lesbian presence at the $4^{\text {th }} U \boldsymbol{N}$ World Conference on Women in Beijing in 1995. It would later be recalled as "the biggest lesbian

27 Ibid at 182.

28 Thoreson gives the story in painstaking detail, 199-204.

29 See Amnesty International USA, Breaking the Silence: Human Rights Violations Based on Sexual Orientation (Amnesty International Publications, 1994).

30 Scott Long had been advocacy coordinator and regional specialist for Europe in IGLHRC. Jessica Stern, the current head of OutRight Action International, the organizations new name, had been on staff with the LGBTI unit in HRW before moving to IGLHRC. In the period ILGA was quite minimal in staff and activity, outside its periodic conferences. Under Julie Dorf, the founding figure of IGLHRC, then based in San Francisco, the organization established a satellite office within the Human Rights Watch office in New York. Dorf proposed that IGLHRC become part of Human Rights Watch, but that was rejected by the IGLHRC board, and Human Rights Watch developed its own separate LGBT unit: see Thoreson, supra note 23 at 36. The two organizations continued to cooperate. In 2003, IGLHRC and HRW jointly published a report: 'More Than a Name: State-Sponsored Homophobia and its Consequences in Southern Africa.' Judith Butler was one of the board members of IGLHRC in the period and reflected on her time as IGLHRC's chair in the preface to the 10th anniversary edition of her book Gender Trouble. Congressman Barney Frank was also on the board.

31 Boris Dittrich later stepped down, to resume a role in domestic electoral politics in the Netherlands. 
visibility campaign in history." ${ }^{32}$ Two or three lesbian organizations gained general accreditation because of the upcoming conference. There was a 'Lesbian Tent' in the NGO conference center. Activists unfurled a banner from the observers' gallery at the intergovernmental conference. It read "Lesbian Rights are Human Rights”. It was quickly removed by security guards.

Many remember the statement of Palesa Beverly Ditsie, from Soweto, South Africa, speaking on behalf of the International Gay and Lesbian Human Rights Commission $^{33}$ and over fifty other organizations. She quoted Nelson Mandela's 1994 condemnation of discrimination on grounds of sexual orientation. She turned to the draft "Platform for Action" that would be the closing statement of the conference:

"Paragraphs 48 and 226 of the Platform for Action recognize that women face particular barriers in their lives because of many factors, including sexual orientation. However, the term "sexual orientation" is currently in brackets. If these words are omitted from the relevant paragraphs, the Platform for Action will stand as one more symbol of the discrimination that lesbians face, and of the lack of recognition of our very existence.”

The inclusion of references to 'sexual orientation' in the draft Platform for Action were in sections dealing with 'diversity' and 'intersectionality'. Inclusion was debated in the drafting committee well into the early pre-dawn of the final day, just hours before the important celebratory closing ceremony. In the drafting meeting, more countries spoke in favor of the references than opposed.

"For many it was an enormous victor that it was discussed at all; for some it was 'a central success of the conference."

At 4:30 in the morning there was a trade-off. The references to 'sexual orientation' would be dropped - along with references to cultural difference as a factor to be considered in the application of women's rights. ${ }^{35}$ There would be no

32 OutRight Action International, Press Release, Exclusive Screening and Discussion about "Lesbians Free Everyone”, a film by Bev Ditsie, March 19, 2021. In 1995, in advance of the Beijing conference, the International Lesbian and Gay Human Rights Commission (now OutRight Action International) published Unspoken Rules: Sexual Orientation and Women's Human Rights, with short sections on 31 separate countries or jurisdictions, including interesting sections on Malaysia, Philippines and Thailand.

33 IGLHRC had been established in 1990 in the United States, with outreach to the Soviet Union and parts of Latin America. The Beijing conference seems its first significant engagement with the United Nations. See Thoreson, supra note 23 at 34. A number of states had already begun to support LGBTI rights, and the rolling draft of the final statement for the Beijing conference had state-generated references to sexual orientation as a factor in assessing women's rights (references that were bracketed, indicating there was not yet a 'consensus' on inclusion).

34 Swiebel, "Lesbian, gay, bisexual and transgender human rights", supra note 2 at 26.

35 Dianne Otto, "Lesbians? Not in my Country" (1995) 20:3 Alternative Law Journal 288-290 at 288; Dianne Otto, "Holding Up Half The Sky, But For Whose Benefit?: A Critical Analysis Of The Fourth World Conference On Women” (1996) 6:1 Australian Feminist Law Journal $7-28$ at 19 and $25-26$. 
fight on the floor. The closing ceremonies would be calm. This debate is well known - unlike the quiet drafting change at the Vienna Conference.

A fascinating 2021 'Beijing Retrospective' video by Beverly Palesa Ditsie, is entitled Lesbians Free Everyone. It has archival material on the Beijing conference, the NGO forum and earlier women's conferences. It includes the speech by Beverly Ditsie to the intergovernmental conference in $1995 .^{36}$

\section{NEXT MOVES}

The South African constitution of 1996 was the first in the world to expressly prohibit discrimination on grounds of sexual orientation. South Africa was also the $5^{\text {th }}$ country to open marriage to same-sex couples.

The next step at the UN, after the failure to gain recognition in the declarations at the Vienna and Beijing conferences, was to try to get support from the Commission on Human Rights (now the Human Rights Counci). A clumsy attempt to get a positive resolution, initiated by two Brazilian diplomats in 2003, seemed to show that such a resolution could not succeed. Active opposition came from member states of the Organization for Islamic Cooperation and others. ${ }^{37}$ Prominent rights academic, Jack Donnelley commented that "in the short and medium term, there is no chance" for a UN resolution on the rights of homosexuals.

In 2005, New Zealand, in the General Assembly, made a statement of support on behalf of 32 States - a statement, not a resolution. There was no vote. The next year the statement was made by Norway on behalf of 54 States. In 2008 the statement was made by Argentina on behalf of 66 States. The US added its name in 2009 and Costa Rica did the same in 2010. A counter statement was supported by 57 States. Roughly one-third of UN members remained silent. ${ }^{39}$ Over time a formal LGBTI Core Group of member states formed to coordinate support, much as the Organization for Islamic Cooperation coordinated most of the opponents.

36 See www. lesbiansfreeeveryone.org.

37 The two diplomats feared the incoming administration in Brazil would not be supportive of LGBT rights. They submitted their resolution, without consulting other delegations, almost at the end of the session, hoping to avoid much scrutiny. Pakistan, representing the Organization of the Islamic Conference (now the Organization of Islamic Cooperation) moved numerous amendments effectively blocking any consideration of the resolution in the dying hours of the closing day of the session. One year later Brazil simply deferred the resolution for another year. In the third year it was allowed to die, without ever being the subject of a serious debate.

38 Jack Donnelly, Universal Human Rights in Theory and Practice, Second Edition, Cornell, 2002, 238, quoted in Thoreson, supra note 23 at 184.

39 Ibid.

40 "Since 2008, the Core Group has grown to include thirty-three countries, plus the European Union, OHCHR, and two NGOs (OutRight Action International and Human Rights Watch). It is chaired by Argentina and the Netherlands and meets every month. To counter the notion that LGBTI rights are a Western imposition, the Core Group has a rule that new members can 


\section{AN 'EXPERTS' MEETING IN YOGYAKARTA}

Leaders from $\boldsymbol{I L G A}$ met with Louise Arbour, the UN High Commissioner for Human Rights. The office of the High Commissioner was fairly new, one of the results of decisions at the Vienna World Conference on Human Rights. As an alternative to focusing on getting a Council resolution, Arbour suggested convening a representative 'expert' group to try to resolve differences and formulate a positive statement on LGBTI rights. What she was proposing was a conclave with representatives from all five UN regions, bringing the different sides together in dialogue. She said that her office would be supportive but would not play a role in this effort. The activists saw opponents as intractable, making a reasoned outcome impossible.

The alternative was to convene an independent 'expert' group, institutionally separate from both member states and the UN. Such a grouping would be following the model of many other similar initiatives over the years. ${ }^{41}$ It was this independent experts' model that the NGOs decided to pursue.

What was being suggested was a very elite strategy, clearly beyond the capacity of existing LGBTI organizations to implement. At the time there was only one person based in Geneva full time, among the three leading LGBTI nongovernmental organizations. Amnesty International and Human Rights Watch were not credible sponsors; they were advocates, already committed. A planning committee emerged, including ILGA, IGLHRC and ARC International. Two well established general human rights NGOs, with offices in Geneva, took the lead. They were the International Service for Human Rights (ISHR) and the International Commission of Jurists (ICJ).

The key figures were Chris Sidoti of ISHR, John Fisher of ARC International and the most important drafter, Michael O'Flaherty, then a member of the UN Human Rights Committee. ${ }^{42}$ O'Flaherty was a major figure in international human rights work. He went on to become director of the Fundamental Rights Agency of the European Union. These three individuals, the first two based in Geneva, were able to assemble a highly credible group of experts, and present a draft of principles for the recognition of LGBTI rights. ILGA and IGLHRC played almost no role in the planning.

only join in pairs, one from the Global North and one from the Global South.” See Trithart, supra note 21 at Box 6. For current membership see https // lgbtcoregroup.org/members/.

41 There were a number of documents formulated outside the structures of the UN by 'experts', intended to be influential in the application of particular matters of international law. One of the best-known documents produced in this way is the Paris Principles on the Status of National Institutions for the Promotion and Protection of Human Rights. Perhaps uniquely, the Paris Principles were adopted by the General Assembly in 1993, and some access to UN forums has followed for such 'national institutions.

42 The UN Human Rights Committee was established to monitor state compliance with the International Covenant on Civil and Political Rights. O'Flaherty was a member of the committee from 2004 to 2012. 
The 29 experts came from 25 countries and all five 'UN regions'. Six were from Asia: China, India, Indonesia, Nepal, Pakistan and Thailand. Four were from Eastern Europe: Bulgaria, Moldova, Poland and Serbia. Four from Africa: Kenya (2), South Africa and Botswana. There was no representative from MENA (Middle East and North Africa), not an official UN region. One was from Turkey, which is grouped in the 'Western Europe and Others' region. Thirteen were holding or had held 'expert' positions within the United Nations human rights system. Eight were serving special rapporteurs (UN independent experts). Others were members of UN treaty bodies, judges, chairs of national human rights commissions, academics and activists. One was Mary Robinson, from Ireland, former UN High Commissioner for Human Rights. Only two had positions in LGBTI UN accredited NGOS. ${ }^{43}$ Chairing the meeting were Professor Vitit Muntarbhorn from Thailand ${ }^{4}$ and Sonya Onufer Correa from Brazil. Chris Sidoti, the prime organizer has said the "unique feature" of the meeting was bringing together both established human rights experts with established LGBTI experts, two solitudes that had not been working together. ${ }^{45}$

During the period of developing the expert's meeting, on July 26, 2006 Louise Arbour, as UN High Commissioner for Human Rights, spoke at the opening dinner of the extraordinary International Conference on LGBT Human Rights held in Montreal, linked with the first Out Games. ${ }^{46}$ There were one thousand, five hundred participants, the largest conference of its kind ever held. Both the conference and the games had support from the city of Montreal, the province of Quebec and the government of Canada. It was a breakthrough to have the UN High Commissioner for Human Rights publicly support LGBTI rights, relying largely on the Toonen decision of the Human Rights Committee. She condemned anti-sodomy laws as well as laws that "prohibit gender reassignment surgery for transsexuals or require intersex persons to undergo such surgery against their will.” She put the right to privacy, a central part of the Toonen decision, in positive terms. It protects

“... those special and unique characteristics that define our existence including our sexual identity. As such, this right is closely related to

43 Maxim Anmeghichean, from Moldova, was with ILGA Europe. Mauro Cabral, of Argentina, was with the Buenos Aires regional office of the International Gay and Lesbian Human Rights Commission, a US based NGO.

44 Professor Muntarbhorn had been the opening speaker at the 2005 Bangkok conference, 'Sexualities, Genders and Rights in Asia: First International Conference of Asian Queer Studies', co-sponsored by Mahidol University, which was the only Asian university at the time to have a graduate program in human rights. Muntarbhorn had been active at the local, regional, and international level on issues of refugees and had been the first Special Rapporteur on the Rights of the Child. The 2005 conference was the first time he addressed LGBTI rights publicly.

45 Personal communication, 7 April 2021.

46 See 2006 World Outgames, with a section on the International Conference, Wikepedia, accessed March 20, 2021. At the first Gay Games, held in Amsterdam, Amnesty International held a companion human rights conference. This pattern of twinned events continued with both the Gay Games and the Out Games. 
the protection of life, human dignity, and mental and physical integrity."

Arbour went on to authorize a study on sexual orientation rights to be done within her office. For this she received some criticism from certain UN member states.

In November, 2006, the Yogyakarta Principles expert group met on the campus of Gadjah Mada University, in Yogyakarta, Central Java, Indonesia. Arrangements were made by Professor Dafri Agussalim, Dean of the School of Social and Political Sciences. The Rector (head) of the University attended the opening and closing ceremonies. ${ }^{47}$

Holding the experts meeting in the global south was designed to counter the accusation that LGBTI rights were simply a 'western' preoccupation. Yogyakarta was a uniquely important jurisdiction in Indonesia. Not only was it of historic and cultural importance, it was the only jurisdiction in Indonesia still actually governed by a sultan. It was south of the equator and in the country with the largest Muslim population in the world. As well, Indonesia had never had a criminal ban on adult consensual homosexual acts. ${ }^{48}$

The experts agreed on the 29 principles that formed the Yogyakarta Principles on the Application of International Human Rights Law in Relation to Sexual Orientation and Gender Identity. ${ }^{19}$ The document relied on existing human rights principles of equality/non discrimination, applying them to LGBTI. The conclusions were based on the application of those principles, not on existing state practice. It rejected any idea of 'new' or 'special' rights. It supported equal treatment for committed couples, but did not support the formal extension of 'marriage' (which had been specifically rejected by the Human Rights Committee in the decision in Joslin $\mathrm{V}$ New Zealand).

The Yogyakarta Principles were a clear success. The document gave a picture of what recognizing LGBTI rights would mean, using the style and language of the UN. In its clear copying of UN style, it was a very pedantic document. Not sexy at all. That seems a key to its success. No radical agenda. The message was 'LGBTI exist, treat them equally'. There was no challenge to the existing systems of handling families and sexualities, which themselves were evolving. Give us a 'seat at the table', as some put it.

Interestingly the definitions in the document - of terms like gay, lesbian, bisexual, transgender, sexual orientation and gender identity - were widely quoted in later documents and government statements. This showed how little LGBTI existence had been acknowledged or discussed by authorities (and therefore a need

47 Personal communications from Chris Sidoti, March 2021.

48 For a period, it had an unequal age of consent for male-male sexual acts, before that inequality was ended in both the Netherlands and the colony.

49 The official 'launch' of the Yogyakarta Principles was held on March 26, 2007, with a series of international events, timed to coincide with the main session of the United Nations Human Rights Council in Geneva. 
for quite introductory namings and definitions). The Yogyakarta Principles moved the issues ahead. The document has been translated into a dozen languages and endorsed by a number of states and inter-governmental organizations.

At a launch event at the UN in New York November $7^{\text {th }}$, 2007, High Commissioner Louise Arbour strongly supported the Yogyakarta Principles:

"Human Rights principles, by definition, apply to all of us, simply by virtue of having been born human. Just as it would be unthinkable to exclude some from their protection on the basis of race, religion, or social status, so too must we reject any attempt to do so the basis of sexual orientation or gender identity. The Yogyakarta Principles are a timely reminder of these basic tenets. ${ }^{{ }^{50}}$

\section{SUCCESS AT THE HUMAN RIGHTS COUNCIL}

For the UN, the crucial date is 2011, when the Human Rights Council, the key 'political' body within the UN system of human rights, condemned violence and discrimination on grounds of sexual orientation and gender identity for the first time. The lead countries who formulated the particular resolution were from Latin America. Politically, it could not be simply the UN's 'western' group that was pushing LGBTI rights. Part of the 'eastern Europe' group now gave support. Three or four states in Asia were also supportive, sometimes.

The 2011 resolution meant that LGBTI rights were now officially on the UN human rights agenda. A study was commissioned. In 2014 a second vote saw the support of a clear majority (no need to rely on abstentions and absentee members to get the resolution passed). The third vote authorized an independent expert. In the fourth vote in 2019 the mandate of the independent expert was renewed with a very comfortable margin of 16 votes.

The UN was following established patterns of advancing particular human rights issues. First the 'expert' parts of the system and top staff came on board. Then there had to be resolutions in the key political human rights body. Then there were studies, two, in this case, by the Office of the UN High Commissioner for Human Rights. Then an independent expert.

In 2013 the OHCHR launched an educational campaign under the slogan "Born Free and Equal", wording taken from the 1948 Universal Declaration of Human Rights. There were videos and publications.

One promotional UN video was in the lavish style of a Bollywood musical. An Indian son was bringing his same-sex partner home to meet the extended family for the first time. At first the matriarch was in shock, but soon there was acceptance -

50 UN Commissioner backs LGBT rights, Pink News, November 12, 2007.

51 Eduard Jordaan, "The Challenge of Adopting Sexual Orientation Resolutions at the UN Human Rights Council” (2018) 8 Journal of Human Rights Practice 1-13. 
and joyful singing and dancing. It was a brilliant attempt to change traditional attitudes.

The "Being LGBTI in Asia" initiative of the UN Development Program, was launched in 2014 with US AID funding. Sweden became a second sponsor. The program held community consultations and interacted with governments. The UNDP published substantial reports on eight Asian countries: Cambodia, China, Indonesia, Mongolia, Nepal, Philippines, Thailand and Vietnam. It was amazing to many activists that this could be done, for national governments had to agree to the process and vet the report in each case. AIDS had been an entry point on LGBTI matters for many UN agencies, but this $U N D P$ program was purely about human rights and economic inclusion. It was the UN's largest-scale programming on LGBTI issues, and to some extent has been copied in other $\boldsymbol{U} \boldsymbol{N}$ regions. ${ }^{52}$

Indonesia protested, but only after having approved the holding of national dialogue meetings, and after participating in the approval of the final national report. Indonesia had moved into a more hostile space on LGBTI rights and told the UNDP to cease any activity on the issues. But the Indonesia project was already completed, and the report was easily available online. ${ }^{53}$

In September 2015, twelve UN entities issued a detailed joint statement calling for an end to violence and discrimination against LGBTI people. In the large UN family, this was a dramatic show of solidarity from the ILO, UNESCO, WHO, UNFPA, UNHCR, UNICEF, UN Women, UNDP, UN AIDS, UNODOC, WFP and, of course, the Office of the UN High Commissioner for Human Rights. ${ }^{54}$ In 2016 the World Bank appointed a special adviser on SOGI issues. Trithart writes that this management-level position has "no equivalent" elsewhere in the international intergovernmental system. UN Women now has an LGBTI advisory position. Work on SOGI issues generally has had to come from special grants outside the core funding of agencies. Sizeable special programmatic grants for SOGI work came from only a handful of countries, notably including the Netherlands, Norway, Sweden, and the United States. ${ }^{55}$

In September 2017, the UN High Commissioner for Human Rights issued a 43-page document 'Tackling Discrimination against Lesbian, Gay, Bi, Trans and Intersex People: Standards of Conduct for Business.'

\section{WHERE ARE WE NOW?}

52 Trithart, supra note 21 at box 4 .

53 The shift in mood in Indonesia was such that the 10th anniversary of the Yogyakarta Principles was moved to Bangkok.

54 "News Release, Twelve UN agencies issue unprecedented joint statement on rights of lesbian gay, bisexual. transgender and intersex people", United Nations Human Rights, Office of the High Commissioner, Geneva, September 29, 2015. The refugee agency had been early in dealing with LGBTI. It formulated guidelines on the handling of LGBTI refugee claims in 2008 and revised them in 2012. A substantial body of reports on LGBTI issues in various countries came into existence to assist decision makers in refugee cases.

55 Trithart, supra note 21 and accompanying text. 
Now more than 30 countries have opened marriage to all couples. Taiwan is the first jurisdiction to open marriage in Asia. Thailand seems likely to provide some recognition system.

There is still "open hostility" by some UN members, and passive resistance to reform by many others. But the new direction seems solid, despite resistance from (a) the member states of the Organization of Islamic Cooperation, (b) sub-Saharan Africa (with South Africa the leading exception), (c) Russia and its loyal neighbors and (d) many small island states in the Caribbean and Pacific.

In Southeast Asia we see regression in Brunei, Indonesia and Malaysia, but some progress elsewhere. In India the Supreme Court ended the colonial era criminal prohibition in 2018, reversing itself to do so. A second attempt to challenge a colonial era anti-homosexual criminal law in Singapore is currently on appeal.

Former UN Secretary General Ban Ki-moon came from conservative South Korea. In a speech in 2015 he said he felt

"...enormous pride in the fact that I have been the first UN Secretary-General to push hard for equal rights and respect for LGBT people around the world.”

Trithart talks of a 'high point' when both Ban Ki-moon and Barrack Obama were in place and strongly supportive.

"Ban Ki-moon is widely seen as having played a critical role in putting SOGIESC on the UN's agenda. He made his first statement on SOGI at a General Assembly side-event in 2010, but it was in his second term that he became a forceful ally. The biggest moment came in 2014 when he granted the spouses of UN staff in same-sex marriages the same benefits as their peers in heterosexual marriages - a move that triggered fierce blowback from some UN member states. Activists saw Ban's outspokenness for LGBTI equality as brave, impactful, legitimizing and surprising, given that it was not an issue he had previously been engaged on. At the end of his term, in 2016, the US and other member states put forward a statement in the UN Security Council thanking Ban for his work on LGBT rights, though it was blocked by Russia. ${ }^{96}$

On the $70^{\text {th }}$ anniversary of the Universal Declaration of Human Rights, Ban's successor, Secretary General Antonio Guterres, addressed the UN Core Group of supportive countries:

$56 \mathrm{Ibid}$, s From Ban to Guterres. 
“...so long as people face criminalization, bias and violence based on their sexual orientation, gender identity or sex characteristics, we must redouble our efforts to end these violations. ${ }^{{ }^{57}}$

The rainbow flag is flying at the $U N$, but not without controversy.

\section{BIBLIOGRAPHY}

Amnesty International USA, Breaking the Silence: Human Rights Violations Based on Sexual Orientation (Amnesty International Publications, 1994).

Borren, Sylvia, Lesbians in Nairobi (Second ILGA Pink Book, 1988).

Bunch, Charlotte, Foreword, Rachel Rosenbloom, Unspoken rules: sexual orientation and women's human rights, International Gay and Lesbian Human Rights Commission, ed (London: Cassell, 1995).

Ditsie, Beverly Palesa, Lesbians Free Everyone Panel (2021).

Greenhalgh, Hugo, "Gay rights groups hail landmark U.N. chief speech backing LGBT+ community”, Reuters (26 September 2018).

Jordaan, Eduard, "The Challenge of Adopting Sexual Orientation Resolutions at the UN Human Rights Council” (2018) 8 Journal of Human Rights Practice $1-13$.

Kayal, Alya Z, Penny L Parker \& David Weissbrodt, "The Forty-Fourth Session of the UN Sub-Commission on Prevention of Discrimination and Protection of Minorities" (1993) 15:2 Human Rights Quarterly 410-458.

McFadden, Robert D, "Larry Flynt, Who Built a Porn Empire With Hustler, Dies at 78”, The New York Times (11 February 2021).

Olcott, Jocelyn, International Women's Year: The Greatest Consciousness-Raising Event in History (Oxford University Press, 2017).

Otto, Dianne, "Holding Up Half The Sky, But For Whose Benefit?: A Critical Analysis Of The Fourth World Conference On Women" (1996) 6:1 Australian Feminist Law Journal 7-28.

— 290 .

Sanders, Douglas, "Getting Lesbian and Gay Issues on the International Human Rights Agenda” (1996) 18:1 Human Rights Quarterly 67-106.

Swiebel, Joke, "Lesbian, gay, bisexual and transgender human rights: the search for an international strategy" (2009) 25:1 Contemporary Politics 19-35.

Thoreson, Ryan R, Transnational LGBT Activism: Working for Sexual Rights Worldwide (University of Minnesota Press, 2014).

57 Hugo Greenhalgh, "Gay rights groups hail landmark U.N. chief speech backing LGBT+ community”, Reuters (26 September 2018). 
Trithart, Albert, "A UN for All? UN Policy and Programming on Sexual Orientation, Gender Identity and Expression, and Sex Characteristics” (2021) International Peace Institute.

Wahyuningrum, Yuyun, Human Rights After Seventy Years: The View from the South, by Yuyun Wahyuningrum (Heinrich Boll Stiftung, 2018).

Douglas Sanders is a Professor Emeritus from Faculty of Law, the University of British Columbia and Emeritus Visiting Professor, Faculty of Law, Chulalongkorn University, Bangkok. He is currently an academic associate at the Institute of Human Rights and Peace Studies, Mahidol University, Bangkok. He is a Canadian citizen, resident in Bangkok since 2003. 